felicitous allusion. He had set before himself as models the best prose writers of the previous century, and the influence of Goldsmith upon him is especially notable. He thus acquired the command of pure, idiomatic and forcible language wherein to clothe the arguments which he wished to enforce, to describe the landscapes which had imprinted themseives like photographs on his memory, and to present restorations of ancient lands and seas which his poetic temperament and powerful imagination called up before his eyes. Moreover, he had a keen sense of humour, which would show itself from time to time, even in the midst of a scientific discussion. He could not bear dulness in others, and strove to avoid it himself. Where his subject might have been apt to grow wearisome, he contrived to lighten it with unexpected flashes of pleasantry or with some pertinent words from a favourite author. This felicitous style seemed so spontaneous, and yet it was in reality the result of the most scrupulous attention. Even in his newspaper articles on the multifarious topics of the passing day, he continued to maintain the same high standard of composition. He has left as his literary monument a series of works that may serve as models of English writing.

In estimating a man's influence on the world we look, not only at his work, but on his character, often the more important and valuable of the two. Judged from this side, Hugh Miller's claims to our regard and admiration are not less strong for what he was than for what he did. Pious and pure-minded, full of generous sympathies, and alive to all that was noblest and best in human life, he was endowed with a manly independence of nature which kept his head erect in every changing phase of his career, and won for him the respect of all, gentle and simple, who came in contact with him. Though naturally robust, his occupation as a mason had left behind some seeds of disease. He was at different times attacked with inflammation of the lungs and other disorders of enfeebled health. His strong sense of duty, however, kept him at his post when prudence earnestly counselled rest. At last the strain became too great, and brought a noble and well-spent life to a sudden and tragic end.

It is to me a valued privilege to take part to-day in the centenary celebration of such a man. The years slip away, and I am probably the only geologist now alive who knew Hugh Miller well. He was my earliest scientific friend. Some boyish articles I had written in an Edinburgh newspaper on a geo. logical excursion to the Isle of Arran had gained me his acquaintance, and ever thereafter I enjoyed his friendship and profited by his encouragement. To his helpful incervention I owed my introduction to Murchison, and thence my entry into the Geological Survey. His death was one of the great bereavements of my youth. It is therefore with heartfelt gratification that here, in his native town, so early familiar to me from his graphic descriptions, I find myself permitted on this public occasion gratefully to express my life-long indebtedness to him for his noble example, for the stimulus of his writings, and for the personal kindness which I received at his hands.

\section{WHAT THE UNITED STATES OF AMERICA IS DOING FOR ANTHROPOLOGY.1}

HAVING recently had the good fortune to pay a somewhat extended visit to the United States of America, I have thought it might not be uninteresting to you to hear what our kinsmen and colleagues across the Atlantic are doing for the furtherance of anthropology.

The means for the advancement of the science of anthropology fall under the following heads :-(I) The collection of information in the field; (2) the publication of such information; (3) the collection of specimens; (4) the preservation of specimens; (5) the publication of museum specimens ; $(6)$ the instruction of students ; $(7)$ independent investigation of collected material.

As no hard and fast line can be drawn between some of these activities, I shall deal first with the museums and with the field work undertaken by the more important institutions in the United States of America, and then very briefly with the teaching of anthropology in the United States.

1 Abridged from the presidential address delivered by Dr. A. C. Haddon, F.R.S. before the Anthropological Institute on January 28 . The addres is published in full in the current number of the Journal of the Institute. NO. I I 3 , vOL. 66$]$

\section{Field Work and Museums.}

It is a glory to the nation of the United States that it has recognised the duty of collecting information about the aboriginal Americans. The twenty or more annual reports published by the Bureau of Ethnology constitute a monument to the intelligence of the Government and of its departmental officials of which their country may well feel proud. Nor does the Bureau of Ethnology neglect the collection of specimens, as is evidenced by the very extensive collections transferred to the National Museum. I cannot, however, refrain from remarking that it seems very strange that the anthropography, or physical anthropology, of the native tribes is entirely neglected by the Bureau, and I know that others share with me the hope that this state of affairs will be remedied.

The head curator of the department of anthropology in the National Museum, Dr. W. H. Holmes, is gradually working out his conception of what his museum should be. His object is twofold: (I) to illustrate the cultural history of mankind; (2) to demonstrate the distinctive characteristics of the various races and people.

(I) Numerous series of objects have been installed to illus. trate the progress of culture, such, for example, as the various stages of evolution from stone implements, on the one hand, to the most modern steel tools and engineering appliances on the other. In this work the curator has been ably helped by the veteran Dr. Otis T. Mason, whose writings on technology are so well appreciated by students. An admirable land transport series has been got together, and one hall is devoted to a wonderful collection illustrating transport by water. There is also an interesting section devoted to comparative religions, of which Dr. Cyrus Adler is the custodian. No Government in the world does so much for ethnology as does that of the United States.

The Free Museum of Science and Art in Philadelphia contains some very valuable and pleasingly arranged collections of Babylonian, Egyptian and Etruscan antiquities. Good representative collections of American ethnology and archæology are being got together, owing to the exertions of Mr. Culin, the director. Of the special collections given to the university, mention need be made only of the collection of gems, of musical instruments and the Furness-Hose collection from Sarawak. In the museum is also to be found Mr. Culin's very instructive and almost exhaustive collection of games, but unfortunately it is stored away in drawers. If this collection was adequately exhibited it would give to the museum a unique position among anthropological museums.

It is instructive to note that although this is a university museum, no support is received from the university, all the scientific work being prosecuted by funds raised from private sources, a result largely due to the enthusiasm of Dr. Sara Y. Stevenson, the energetic secretary of the department.

In I 869 a little band of public-spirited men was created by the Legislature "a body corporate by the name of "the American Museum of Natural History,' to be located in the city of New York, for the purpose of establishing and maintaining in said city, a Museum and Library of Natural History; of encouraging and developing the study of Natural Science; of advancing the general knowledge of kindred subjects, and to that end of furnishing popular instruction and recreation."

A partnership, under sanction of the law, was entered into by the citizens of New York in their corporate capacity with the president and trustees of the museum, it being mutually agreed that the city should pay for the erection of the buildings, their maintenance and protection, while the trustees took upon themselves the responsibility of providing the exhibits, the library, the lectures and other means of instruction and mental recreation. This arrangement is perpetual and irrevocably binding on both parties.

The anthropological department of the museum has accomplished an unprecedented amount of research during the past year, a large sum of money having been received from private sources for the purchase of several important collections of American archæology and ethnology and for the expenses of many expeditions in the field.

The greater part of the anthropological collections in the Yale University Museum are archæological in character. The Peabody Museum of Harvard University is already overcrowded and fresh collections are constantly arriving, which the curator, Prof. F. W. Putnam, is forced to keep in boxes in the store rooms. The main collections are the results of the 
digging of mounds in the Eastern and Central States; thus the archæology of that portion of America can be very well studied in the museum. During the years 1887 to 1893 the late Mrs. Mary Hemenway provided funds for archæological and ethnological expeditions to the Pueblo Indians of Arizona and New Mexico.

The history of the progress of anthropology in Chicago is eminently characteristic of that typical American city.

There is no need to give a detailed history of the anthropological department of this museum, as Dr. Dorsey has already done so in the American Anthropologist, n.s., ii. I890, p. 247 ; but I will briefly indicate the main collections and their origin.

The anthropological collections which formed the foundation of the department were obtained through special expeditions sent out under the direction of Prof. F. W. Putnam, or by collectors resident in the field, who were commissioned by the department of ethnology to undertake the work. A mass of interesting and valuable material from Alaska to Peru was thus accumulated. A few collections from other quarters of the globe were also obtained. The history of the museum since then has been one of almost unparalleled activity. Expedition after expedition has been sent out to collect ethnological and archæological material in North and Central America; some of these have been paid for out of the museum funds, while others have been rendered possible by special donations from benefactors, most of whom are Chicago merchants.

The more technical aspect of the museum has been so well described by Dr. A. B. Meyer that I need not dwell upon it.

The most recent inauguration of anthropological activity is that displayed by the University of California. A department of anthropology was established by the Regents of the University in September, I90I.

As an encouragement to others and as an expression of her great interest in the new department, Mrs. Phœbe A. Hearst, who is one of the Regents and a most generous benefactor to the University, has promised $10,000 \%$. (50,000 dollars) a year for five years for anthropological research. In this manner is struck the key-note of the new department. Research first and foremost. We may look forward in the immediate future to the establishment of a really important museum on the Pacific coast which, being under the jurisdiction of the University of California, will be the centre of considerable anthropological research and instruction.

Now that the financial position of the Stanford University at Palo Alto is permanently secured, it is to be hoped that the claims of anthropology will not be overlooked.

This is not the place to describe the points of interest in the various museum buildings, the installation of the collections and the details relating to museum administration and technique. It is the less necessary as Dr. A. B. Meyer, of Dresden, who is a recognised authority on all matters pertaining to museums, travelled in the United States in 1899 , and he is publishing a series of well-illustrated reports on the institutions he visited. These reports are invaluable to all those who are interested in the promotion or maintenance of museums and libraries, and it is to be hoped that no architect in the future will attempt to draw up plans for a new museum or library until he has consulted this work.

\section{The Teaching of Anthropology in the United States of America.}

In America courses of anthropology were established about fifteen years ago at Harvard University and at the University of Pennsylvania. It was one of the first subjects introduced into the curriculum of the University of Chicago. Seven or eight years ago anthropology was recognised in Columbia University in the city of New York. At the present time some thirty-three universities and colleges offer instruction in anthropology. Limit of space precludes my giving details concerning the instruction in anthropology in these numerous institutions, so I confine myself to a consideration of two of the universities where the teaching is most firmly established. Further information on this subject will be found in Prof. G. G. MacCurdy's report on "The Teaching of Anthropology in the United States" in Science, n.s., vol. xv. 1902, p. 21 I.

It would be impossible to include within the limits of a brief 1 The two parts already issued are entitled "Ueber Museen des Ostens
der Vereinigten Staatne von Nord Amerika.". Reisenstudien von A. B. Meyer. (Berlin: R. Friedländer und Sohn.)

$$
\text { No. } 1713 \text {, voL. 66] }
$$

address an account of all the work that is being done in anthropology by the Government, by public and private institutions, or by individual effort in the United States of America. Much as I should have liked to have emphasised the interest exhibited in the subject and the wonderful activity that is being displayed, the bare enumeration of all this activity would make a very weary chronicle.

I must confess that I felt a not inconsiderable amount of envy when on every hand I witnessed this energy and then recalled the apa thy which pervades our own country.

The American public is more intelligently alive to the interest and importance of anthropology than is our public. The exponents of the science are energetic, enthusiastic and competent, and they succeed in gaining the practical sympathy of wealthy merchants, who are not averse to spending money freely when they see that the money will be wisely spent for the good of the State or of the city. One cannot say that the wealthy Americans are more intelligent than are our rich men, but they do seem to appreciate the value of learning to a much greater extent than do ours. At all events, they respond more readily to the very pressing need there is for the endowment of research and of those institutions which bring the knowledge of the expert down to the comprehension of the masses.

I am quite willing to admit that the fault in this country may lie as much with the specialist as with the capitalist. In any case we have an inspiriting demonstration in the United States of America of what can and should be done in Great and Greater Britain, and I venture to thank our American colleagues in the name of anthropological science for this good example of strenuous effort and praiseworthy accomplishment.

\section{UNIVERSITY AND EDUCATIONAL INTELLIGENCE.}

THE new municipal school of technology in Manchester will be opened by Mr. Balfour on October I 5 .

Dr. W. Palmer Wynne, F.R.S., professor of chemistry in the School of Pharmacy of the Pharmaceutical Society, will deliver an address at the inauguration of the sixty-first session of the School on October I.

Mr. PARKIN, who has just gone to America to formulate a plan for putting into execution the provisions of Mr. Cecil Rhodes's will, has, a correspondent of the Times reports, been trying to interest Mr. Pierpont Morgan in a plan whereby the Rhodes scholarship scheme should be made reciprocal, the same number of young Englishmen being educated at American universities as Americans at Oxford. When he landed at New York on August 20, Mr. Parkin said:-" I think it would be a most splendid thing for some liberal American, or several Americans, to endow in some of your great colleges scholarships for the benefit of English youths similar to those founded by the bequest of Mr. Rhodes for the young men of America at Oxford." The same idea was put forward in several American papers when the terms of Mr. Rhodes's will were announced.

THE Childhood Society was founded some five years ago by the late Sir Douglas Galton, and, as its fifth annual report shows, it continues to grow in importance and usefulness. The objects of the Society are to promote the study of educational methods and of the environment of children during school life, with a view to discover the conditions best suited to ensure the healthy mental and physical development of normal children, and those best adapted to the peculiar needs of the mentally feeble and otherwise abnormal children. For the first time, the council of the Society has printed and issued the lectures and papers delivered at its meetings in book form, under the title of "Volume I. of the Transactions of the Childhood Society." A glance through the list of the Society's officers for the current year reveals a desirable cooperation between medical men and professional educationists which cannot fail to result in an im. provement in the structure and equipment of schools as well as in the less material conditions of the class room.

A RECENT return printed by the order of the House of Commons, tabulating the sums applied by local authorities to the purposes of technical education, shows that the total amount expended on technical education in England and Wales during I $900-1$ was I,05I,422l.; but this does not include sums allocated to interm,ediate and technical education under the Welsh Intermediate Education Act. The total amount of 